\title{
Laboratory and image spectroscopy for evaluating the biophysical state of meadow vegetation in the Krkonoše National Park
}

\section{Abstract}

The paper deals with the evaluation of mountain meadow vegetation condition using in-situ measurements of the fraction of Accumulated Photosynthetically Active Radiation (fAPAR) and Leaf Area Index (LAI). The study analyses the relationship between these parameters and spectral properties of meadow vegetation and selected invasive species with the goal of finding out vegetation indices for the detection of fAPAR and LAI. The developed vegetation indices were applied on hyperspectral data from an APEX (Airborne Prism Experiment) sensor in the area of interest in the Krkonoše National Park. The results of index development on the level of the field data were quite good. The maximal sensitivity expressed by the coefficient of determination for $L A I$ was $R^{2}=0.56$ and $R^{2}=0.79$ for fAPAR. However, the sensitivity of all the indices developed at the image level was quite low. The output values of in-situ measurements confirmed the condition of invasive species as better than that of the valuable original meadow vegetation, which is a serious problem for national park management.

Keywords

$\mathrm{LAl} \cdot \mathrm{fAPAR} \cdot$ hyperspectral data $\cdot$ meadow vegetation $\bullet$ invasive species - the Krkonoše National Park

(C) University of Warsaw - Faculty of Geography and Regional Studies

\author{
Jan Jelének ${ }^{1}$, Lucie Kupková ${ }^{2}$ \\ Bogdan Zagajewski ${ }^{3}$, Stanislav Březina ${ }^{4}$, \\ Adrian Ochytra ${ }^{5}$, Adriana Marcinkowska ${ }^{6}$ \\ 'Department of Applied Geoinformatics and Cartography \\ Faculty of Science \\ Charles University in Prague \\ e-mail: jan.jelenek@gmail.com \\ Department of Applied Geoinformatics and Cartography \\ Faculty of Science \\ Charles University in Prague \\ e-mail: lucie.kupkova@gmail.com \\ ${ }^{3}$ Department of Geoinformatics and Remote Sensing \\ Faculty of Geography and Regional Studies \\ University of Warsaw \\ e-mail: bogdan@uw.edu.pl \\ ${ }^{4}$ The Krkonoše Mountains National Park administration \\ e-mail: sbrezina@krnap.cz \\ ${ }^{5} \mathrm{College}$ of Inter-Faculty Individual Studies in \\ Mathematics and Natural Sciences \\ University of Warsaw \\ Department of Geoinformatics and Remote Sensing \\ Faculty of Geography and Regional Studies \\ University of Warsaw \\ e-mail: adrian.ochtyra@uw.edu.p \\ Department of Geoinformatics and Remote Sensing \\ Faculty of Geography and Regional Studies \\ University of Warsaw \\ e-mail: adriana.marcinkowska@student.uw.edu.pl \\ Received: 10 October 2013 \\ Accepted: 13 March 2014
}

\section{Introduction}

This paper deals with possibilities for the evaluation of health/condition of meadow vegetation and selected invasive species using the in-situ measurements of fAPAR and LAI parameters. The study analyses the relationship between these parameters and spectral properties of meadow vegetation with the goal of finding out the vegetation index for the detection of fAPAR and LAl. The developed vegetation indices were applied on hyperspectral data from an APEX (Airborne Prism Experiment) sensor in the area of interest in the Krkonoše National Park.

Many studies dealing with meadow analysis aim to determine the biochemical/ biophysical parameters that could be used as a spectral indicator of meadow health. They are often focused on nitrogen. Increased nitrogen content in leaves leads to significant changes in plant spectral properties (Ramoelo et al. 2011). A higher nitrogen content causes a shift of the red edge inflex point to longer wavelengths, a significant feature that can be used for remote sensing spectral mapping (Mutanga \& Skidmore 2007; Skidmore et al. 2010). Besides nitrogen, phosphorus, magnesium, health/ condition analysis. polyphenolics and some other substances can also be used (Mutanga et al. 2004). It has also been proved that a higher content of these substances is correlated with a decrease in meadow biodiversity (Klimek et al. 2007).

Traditionally managed meadows are one of the most valuable ecosystems in the Krkonoše Mountains National Park (Czech Republic). Their natural composition, diversity and value are endangered due to the introduction of invasive species over recent decades. Growths of Lupinus polyhpyllus and Rumex alpinus (which is invading the meadow zone due to long term fertilization with nitrogene compounds) are expanding in the Krkonoše Mountains and need to be monitored.

Traditional field meadow monitoring is very time consuming. Remote sensing methods and image data can be very strong tools for the improvement of vegetation monitoring. Apart from the spatial expansion of invasive plants, monitoring remote sensing analyses can help to evaluate current meadow state and can provide a complex automatic algorithm for mountain meadow 


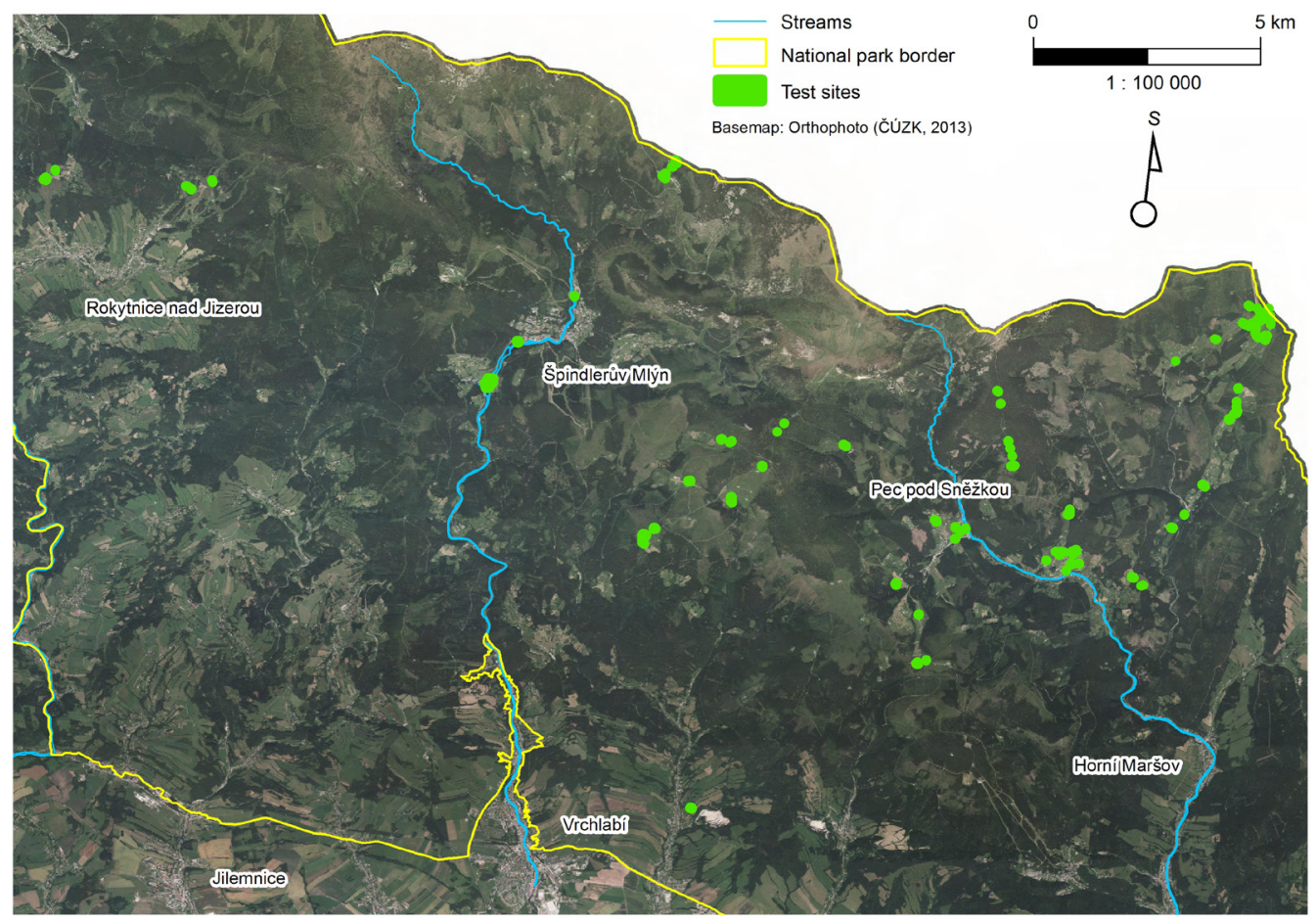

Figure 1. Study area with polygons selected for biophysical and spectral measurements

Vegetation health can be evaluated based on biochemical or biophysical indicators. Leaf pigments like chlorophyll or carotenoids are important biochemical indicators. Chlorophyll content indicates vegetation health and it also has very characteristic spectral properties (Si et al. 2012; Sampson et al. 2003; Malenovský et al. 2013).

One of the biophysical indicators used in this study is fAPAR (fraction of Absorbed Photosynthetically Active Radiation). fAPAR is defined as the share of incoming sun radiation which is absorbed by leaves in the spectral range $400-700 \mathrm{~nm}$ (Fensholt et al. 2004):

fAPAR $=\frac{\left(\mathrm{PAR}_{0}+\mathrm{PAR}_{\mathrm{s}}\right)-\left(\mathrm{PAR}_{\mathrm{c}}+\mathrm{PAR}_{t}\right)}{\mathrm{PAR}_{0}}$

where $P A R_{0}$ is total incoming solar radiation, $P_{A} R_{s}$ is total radiation reflected from the soil (ground), $P_{A} R_{c}$ is total radiation reflected from the canopy level and $P A R_{t}$ is total radiation transmitted through the vegetation on the ground.

This parameter is related to primary vegetation production (photosynthesis). It is possible to relate fAPAR directly to $\mathrm{CO}_{2}$ binding in leaves and current vegetative stage of the plant can also be determined using fAPAR.

The relationship between vegetation indices and fAPAR was studied, for example, in Fensholt et al. (2004). The most widely used index for fAPAR prediction is NDVI (Normalized Difference Vegetation Index); the relation found between fAPAR and NDVI is usually linear (Fensholt et al. 2004; Myneni \& Williams, 1994).

The next most commonly used biophysical indicator is LAI (Leaf Area Index). This index gives information about soil cover by examining the vegetation density, and can express the strength and vitality of the vegetation. It is again possible to find a relationship between $\mathrm{LAI}$ and vegetation spectral properties, and LAI can be used as a biophysical parameter and characteristic feature for particular vegetation species (Darvishzadeh et al. 2008). $\mathrm{LAI}$ is calculated as share of leaf area and soil area. The formula has developed over time in order to take into consideration further leaf features - for example, the slope of the leaf towards the surface, leaf type or shape of needles. LAI is an important measure that can be used for vegetation stress and health/ condition evaluation. It is possible to use LAI for the evaluation of evapotranspiration, analysis of carbon flow or photosynthesis (Zheng \& Moskal 2009).

The goals of this study were:

- in-situ measurements of biophysical parameters, indicating current vegetation health status,

- evaluation of in-situ measurements of the mountain meadows in the Krkonoše National Park,

- development of vegetation spectral indices for the prediction of the biophysical parameters LAI and AAPAR at the level of field and image data,

- $\quad$ application of the developed vegetation spectral indices on aerial hyperspectral data with the goal of producing maps of biophysical parameters,

The research was conducted in the framework of the European Facility for Airborne Research Transnational Access (EUFAR TA) - project HyMountEcos (Hyperspectral Remote Sensing for Mountain Ecosystems - a joint project between University of Warsaw and Charles University in Prague).

\section{Subject of study}

The APEX data were acquired for the whole area of the Krkonoše National Park (both the Czech and Polish sides). The study area (see Fig. 1) covers the whole Czech part of the national park (the western border is near to Kořenov and Rejdice and the eastern border is near to Pomezní boudy, Horní Alberice and Svoboda nad Úpou). Sites of selected meadow vegetation and invasive species for biophysical and spectral measurements were selected at different altitudes over the whole study area (Fig. 1). 
Several categories of the meadow vegetation legend proposed by a botanist from the national park were selected for measurement of spectral properties and biophysical parameters:

1. meadows dominated by Nardus stricta,

2. meadows dominated by Trisetum flavescens, Dactylis glomerata or Alopecurus pratensis,

3. lawns

4. meadows dominated by Vaccinium sp. and Caluna sp.

In addition to meadow vegetation, two invasive species were evaluated:

\section{Rumex alpinus}

6. Lupinus polyphyllus.

\section{Data}

In-situ field data of FAPAR and LAI, field spectral measurements and hyperspectral APEX sensor data were used in the study.

Measurements of fAPAR were conducted using AccuPAR Ceptometer model 80 (Decagon Devices Inc.). Ten measurements were taken in each polygon and their average was calculated and used for analysis. The instrument LAI 2000 Plant Canopy Analyzer (Li-Cor Biosciences) was used to collect LAl data. The principle is based on repeated measurements of the amount of incoming radiation to the lens over the leaf's surface and under the leaf's surface (on the ground). Field spectral measurements were conducted using ASD FieldSpec 4 spectroradiometer (ASD Inc.). Spectra for atmospheric calibration were measured for both bright and dark targets - water areas, asphalt, big metal roofs etc. Spectra for all legend categories were also measured, for 111 polygons altogether. A minimum of 12 spectra were taken for each measured polygon and the spectra were averaged.

As for image APEX data, 15 flight lines were acquired that cover the whole area of the national park on both the Polish and Czech sides and additionally 4 short lines were acquired with the centre situated on the top of Sněžka Mountain for BRDF (Bidirectional Reflectance Distribution Function) effect correction. The average flight altitude was $5800 \mathrm{~m}$ above the surface. The spatial resolution varied from $3.3 \mathrm{~m}$ to $2.4 \mathrm{~m}$. Spectral image resolution was $4 \mathrm{~nm}$ in NIR and $9 \mathrm{~nm}$ in the SWIR region.

\section{Methods}

Sensitivity analysis was performed as a very important part of the development of new vegetation indices. Sensitivity analysis has been used as a tool for vegetation index behaviour analysis and validation in several studies (Zarco-Tejada et al. 2001; Gong et al. 2003; Thenkabail et al. 2000; Tian et al. 2011). In our case the method was used in a similar way to the study by Roberts et al. (2012) for retrieval of the most sensitive wavelengths for the measured parameters (LAI, fAPAR). This analysis is based on Pearson's correlation coefficient. The relation between radiation values and values of vegetation parameters (LAI, fAPAR) was evaluated. The most sensitive wavelengths, which exceeded the critical value of the T-test for validity of relevant measurements (Zvára, 2003; Zagajewski \& Jarocinska 2009), were used as spectral features. Finally, the values were used as a coefficient of determination. The output of this analysis was a dataset of significant spectral features, which were used for the construction of vegetation indices. The final indices were used to produce maps of LAI and fAPAR parameters for the study area. During the process of index construction, relevant problems mentioned in the literature, such as LAI saturation (Wang 2007) and dependence of LAI and chlorophyll content (Haboudane et al. 2004), were taken into account.
The significant spectral features were included in the vegetation index formulas - SR (Simple Ratio) and NDVI (Normalized Difference Vegetation Index) - and also in the newly constructed vegetation indices. Two constructions were used for the final vegetation indices:

1) $S R($ fAPAR):

$R_{M A X}$ Cit (fAPAR)

$\overline{R_{M I N C i t}(f A P A R)}$

2) Proposed formula for $L A I$ index construction:

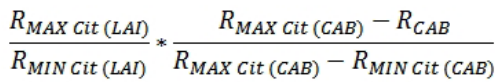

This construction is based on the RISR index (Gonsamo \& Pellikka 2012) where the authors, following the example of the RSR index (Brown et al. 2000), normalized values in the red spectral range for a given pixel using the overall range of reflectance values for this spectral range from the entire image. The output was used for ISR index correction (Fernandes et al. 2003). This enables the reduction in the influence of soil on vegetation reflectance. An assumption of our study was that this principle is also applicable to the reduction of chlorophyll influence on LAI.

Vegetation indices were constructed for airborne image data because it was not possible to use those indices developed based on field spectral data as image data. Map outputs of LAI and fAPAR parameters for the whole study area were prepared in SW ENVI. Each pixel of the final raster has a value calculated based on the applied vegetation index.

\section{Results}

Results of field data analysis

Based on the outputs of the LAl field measurement analysis we can conclude that the analysed invasive species have higher average LAI values than meadows and coniferous trees (Fig. 2). Lawns, on the contrary, have a very low average LAl. The optimal range of the LAI index oscillates between 3 and 5 . The average LAI value for invasive species is 5.3 , for all meadows 2.9 , for lawns 0.8 , and for Vaccinium myrtillus associations almost 4 . Invasive and expansive plants like Rumex alpinus, Lupinus Polyphyllus or Urtica dioica $(\mathrm{LAI}=6.2$ ), but also Vaccinium myrtiillus or meadows rich in Trifolium sp. ( $\mathrm{LAI}=5.3$ ), form very dense cover impenetrable to solar radiation used for the growth of other species. Meadows with Nardus stricta (where Nardus stricta is the dominant species) form lower growths with less dense cover and lower species diversity. LAI values are therefore lower and less variable (standard deviation 0.4 ; standard deviation of other categories is higher than 1). Meadows with Trisetum flavescens have higher species diversity and this is also reflected in a higher variance around the mean value $(=1.5)$.

Values of fAPAR indicate vegetation health. The fAPAR value of a plant in good condition is above $0.8(80 \%$ of incoming PAR), very often close to a value of 1 . There exists a significant difference in fAPAR between invasive species, meadows and lawns (Fig. 3). The results of the measurement showed very good condition of all invasive and expansive growths. All values measured for invasive species were higher than 0.91 and were evaluated as significantly above average. The standard deviation in this case has a value of only 0.015 ; this indicates very small differences and, based on these results, we can assume that invasive species will prosper very well in the whole area of the Krkonoše Mountains. High values were also reached for coniferous forests. Growths of Vaccinium myrtillus also had quite high values of fAPAR but this result may be influenced by the relatively low number of measurements. Lawn, as an artificial meadow vegetation under high stress due to frequent cutting, yielded very low values of fAPAR. The measurements proved 


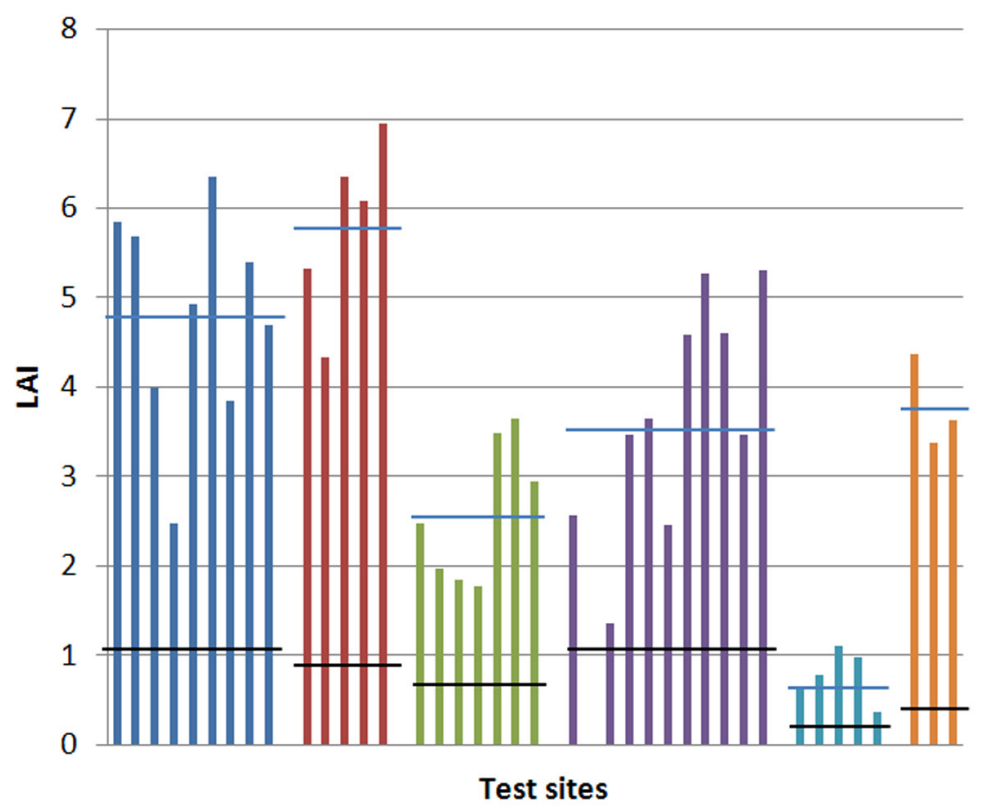

- Rumex alpinus

- Lupinus polyphyllus

Meadows with Nardus stricta

Meadows with Trisetum flavescens

- Lawn

- Vaccinium myrtillus

Mean

- Standard deviation

Figure 2. Values of LAI measurements

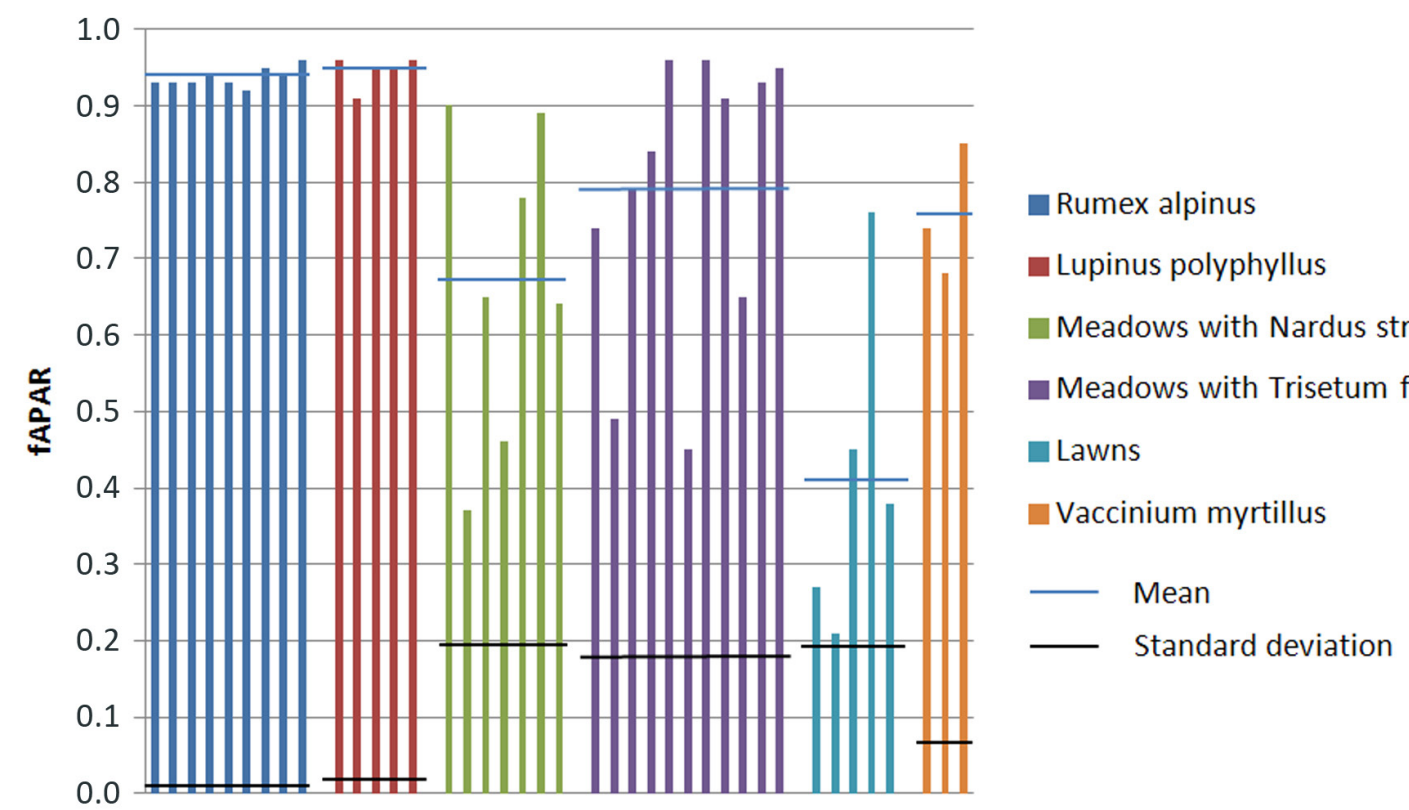

Test sites

Figure 3. Values of fAPAR measurements

a general pattern of higher vitality for meadows with Trisetum flavescens and lower vitality for meadows with Nardus stricta.

The results of index development on the level of the field data were quite good. The maximal sensitivity expressed by the coefficient of determination for $\mathrm{LAI}$ was $\mathrm{R}^{2}=0.56$ and $\mathrm{R}^{2}=0.79$ for fAPAR. However, these indices could not be used for airborne image data because the values of sensitivity were very low. They were not used for map preparation.

Results at the level of image data

The two indices that were the most sensitive towards fAPAR and LAI on the level of image data were used for map production:

$$
\begin{aligned}
& \text { Index } f A P A R=\frac{R_{709}}{R_{2346}} \\
& \text { Index } L A I=\frac{R_{699}}{R_{2346}} * \frac{R_{749}-R_{586}}{R_{749}-R_{490}}
\end{aligned}
$$

The dependence of LAI and fAPAR was recorded for the LAI index (Fig. 4). This dependence is not further resolved in this study and is a subject for further work. The fAPAR index is sensitive only towards fAPAR (Fig. 5); nevertheless, the value was only 0.11 . A better value was reached for the $L A I$ index $\left(R^{2}=0.13\right)$ and the point distribution is also better (compare Fig. 4 and 5), but it is not possible to find any clearly defined trend. The LAI and 


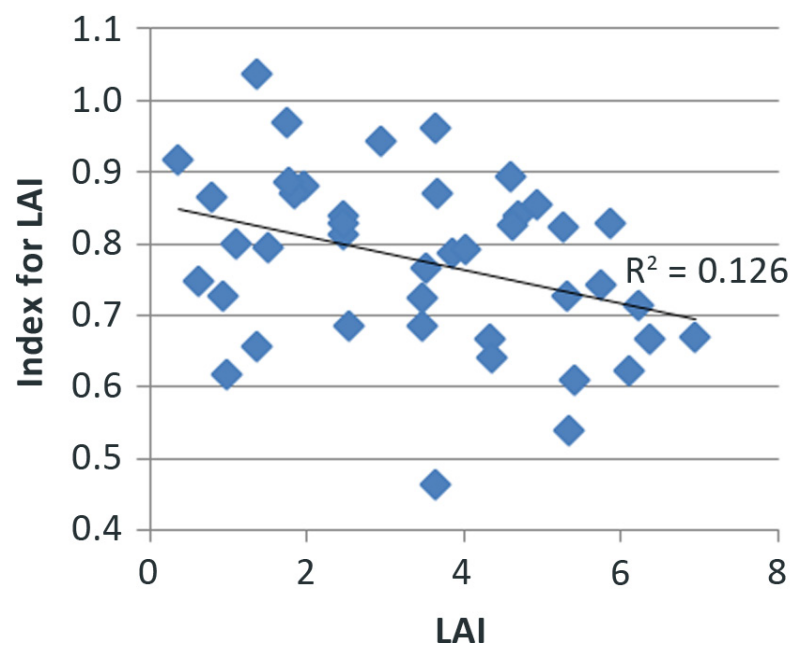

Figure 4. Dependence of developed vegetation indices on LAI

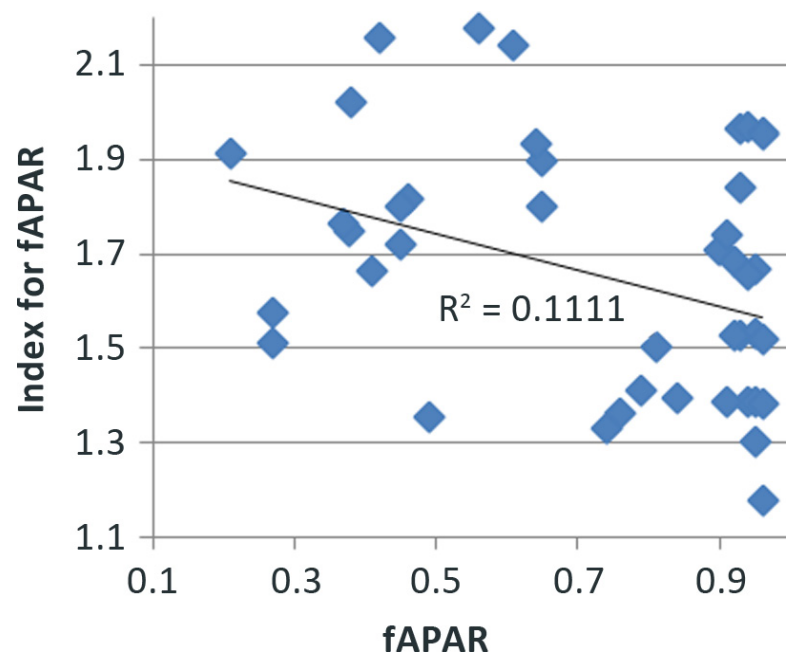

Figure 5. Dependence of developed vegetation indices on fAPAR

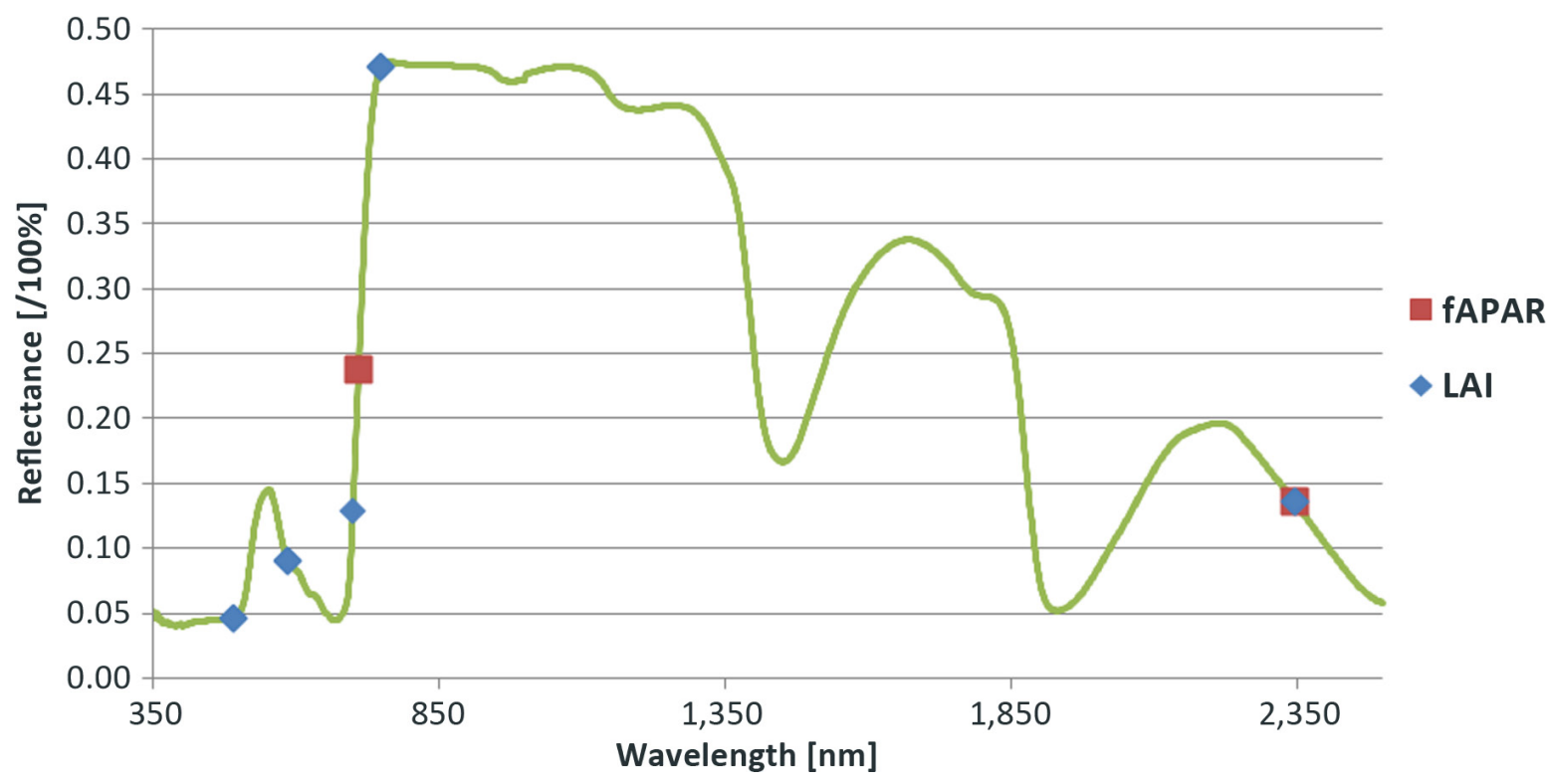

fAPAR indices use a wavelength of $2346 \mathrm{~nm}$ as an insensitive wavelength (Fig. 6), but the SWIR2 region showed significant noise in the image data. The correlation may therefore be false. The fAPAR index uses $709 \mathrm{~nm}$ as a sensitive wavelength in the region of the red edge inflection point (REIP) position (Fig. 6). In the case of the LAl index the sensitive wavelength is $699 \mathrm{~nm}$. This wavelength is also in the characteristic region of a rapid increase in vegetation reflectance (red edge range). Moreover, the LAl index corrects the share of the aforementioned wavelength from the chlorophyll influence. Chlorophyll is represented by wavelengths of $586 \mathrm{~nm}$ (the maximal absorption of chlorophyll in the green portion of the spectrum) and $490 \mathrm{~nm}$ (the region of main absorption of chlorophyll $b$ on the border with chlorophyll absorption in the green spectral range). Wavelengths of $749 \mathrm{~nm}$ are also included in the index which is at the top of the red edge area, i.e. in the position of maximal vegetation reflectance in the NIR region.

The vegetation indices were applied on the image data and final raster layers with calculated index values overlaid on the study area orthophoto (ČÚZK 2013). Because the study area is very extensive, only selected parts are presented in the maps of LAI and FAPAR parameters - the area of Rokytnice nad Jizerou for the LAI index (Fig. 7) and the area of Pec pod Sněžkou and Velká Úpa for the fAPAR index (Fig. 8).

Discussion and conclusions

The goal of the study was to propose and apply a method that relates the biophysical parameters of LAI and fAPAR to significant spectral features of meadow vegetation and invasive species.

Airborne hyperspectral image data from an APEX sensor, field spectral data and instrumental measurements of LAl and FAPAR parameters were used in this study. Though the instruments for LAl and fAPAR measurements are based on the best technologies, the output values may still contain some level of error, which may also be attributable to the changeable field conditions (current meadow management etc.).

As for data processing on a general level, one of the most important problems mentioned, for example in Haboudane et al. (2004), is the dependence of LAl on chlorophyll content which influences the validity of LAl prediction based on vegetation indices. This problem was resolved in this study by the special

Figure 6. Location of wavelengths used in LAI and fAPAR indices 


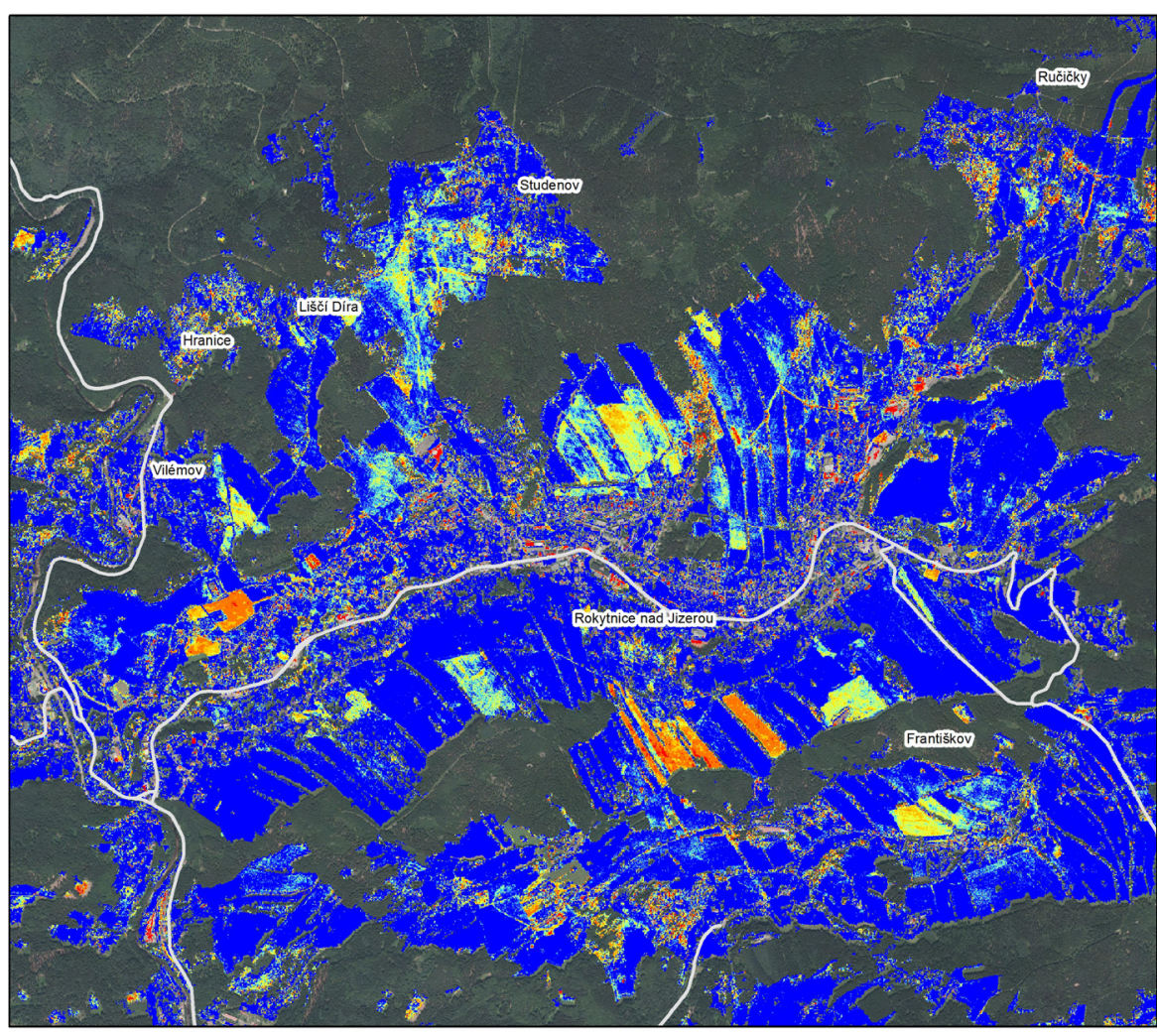

Index for LAI

Rokytnice nad Jizerou

Roads

LA
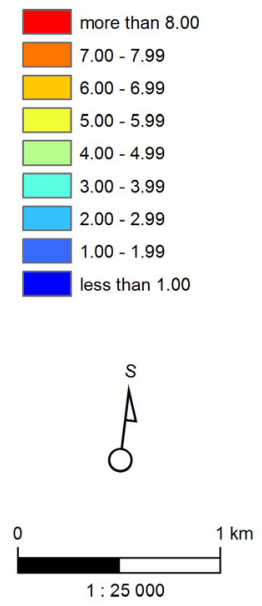

Basemap: Orthophoto (ČÚZK, 2013)

Author: Jan JELÉNEK, 2013

Figure 7. LAI index for the Rokytnice nad Jizerou area

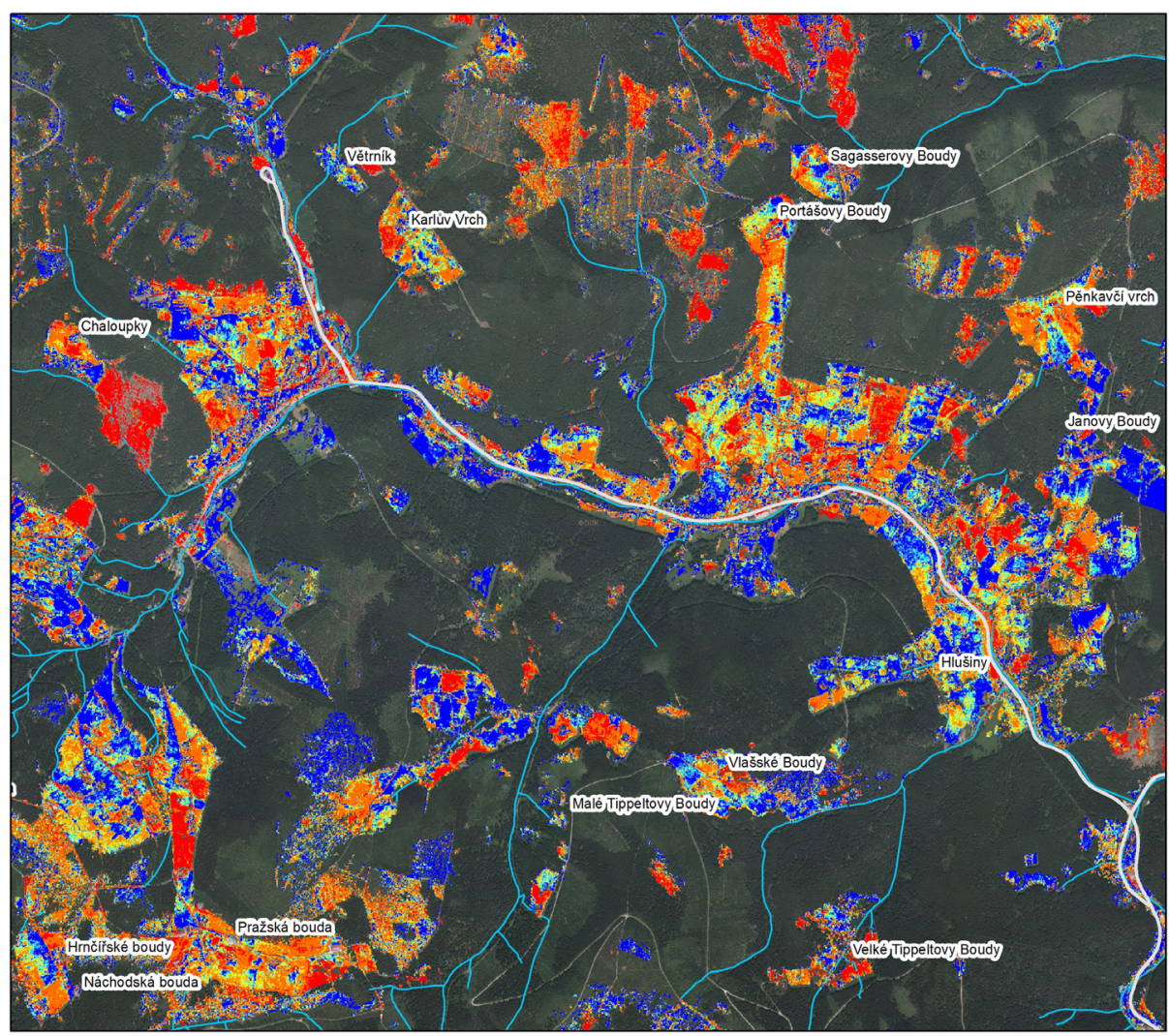

Index for fAPAR

Pec pod Sněžkou, Velká Úpa

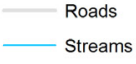

fAPAR
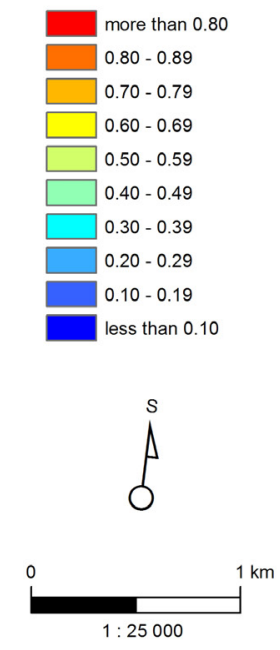

Basemap: Orthophoto (ČÚZK, 2013)

Author: Jan JELÉNEK, 2013

Figure 8. fAPAR index for the Pec pod Sněžkou and Velká Úpa area 
construction of SR and NDVI indices. These indices were corrected using chlorophyll normalization. The methodical approach of Gonsam \& Pellikka (2012) was used for this correction. The final results show a significant decrease in the corrected LAI index sensitivity on chlorophyll content. The final proposed corrected indices are able to separate the influence of chlorophyll and the influence of LAI on vegetation indices focused on LAI prediction. This enables a significantly better classification of those categories that are characterized by a specific value of LAI.

A further problem of the LAI prediction indices was the saturation of index values at particular LAI values. This is generally observed for higher LAI values, while for instance in the case of the NDVI index, the LAI value is around 2 or 3 (Wang 2007). This problem was partly eliminated by the developed method but a fully linear relation of index values and LAI was not reached. This problem was found to be complex as the saturation of fAPAR at the developed index values was also discovered. This saturation was not mentioned in the literature but we can assume that other authors also had to face this problem.

Sensitive and insensitive wavelengths for each classification class were found using a sensitivity analysis (Roberts et al. 2012). This method proved highly effective.

The most problematic step of the approach was the transfer from laboratory level to image data level. Very good results were achieved at the laboratory spectra level but it was not possible to confirm these results at the image data level. The differences between laboratory/ field spectra and image spectra lead to the development of new indices based on the aerial image data. The sensitivity of all indices developed on the image level was quite low and the values were not significant.
The final maps prove the potential of this method and have only an illustrative value. Besides the different natures of laboratory and image data, a very significant reason for this result could be the low number of field measurements. Therefore we can recommend collecting a significantly large dataset of in-situ data that will cover the variability of meadow vegetation. In spite of the less-than-desirable results at the image data level, there is great potential in the combination of biophysical parameter measurements and image spectral data analysis for the future.

The evaluation of vegetation health/ condition using insitu data was successful. The instruments used proved to be very powerful tools and the approach is very promising when used in the practice of national park management. The output values confirmed the condition of invasive and non-original anthropogenic associations of no ecological value as better than that of the valuable original meadow vegetation, which is a serious problem for national park management. Measurement insitu indicated that in some cases the original meadow vegetation surrounding growths of invasive species can be in a worse condition than the same type of original vegetation in localities without invasive species.

\section{Acknowledgements}

The authors give thanks to the European Facility for Airborne Research Transnational Access (EUFAR TA), which funded the flight campaign, to the German Space Agency for execution of the flight and to VITO Belgium for the APEX data acquisition and preprocessing. We also wish to thank the Czech Krkonoše National Park and Polish Karkonoski National Park administrations for provision of the data, for their help during the field campaign and for their collaboration.

\section{References}

Brown, LA, Chen, JM, Leblanc, SG \& Cihlar, J 2000, 'Shortwave Infrared Modification to the Simple Ratio for LAI Retrieval in Boreal Forests: An Image and Model Analysis', Remote Sensing of Environment, vol. 71, no. 1, pp. 16-25.

ČÚZK 2013, Geoportal ČÚZK. Přístup k mapovým produktům a službám resortu. Available from: <http://geoportal.cuzk.cz>. [9 September 2013]

Darvishzadeh, R, Skidmore, A, Schlerf, M, Atzberger, C, Corsi, F \& Cho, M 2008, 'LAl and chlorophyll estimation for a heterogeneous grassland using hyperspectral measurements', ISPRS Journal of Photogrammetry and Remote Sensing, vol. 63, no. 4, pp. 409-426.

Darvishzadeh, R, Skidmore, A, Schlerf, M \& Atzberger, C 2008, 'Inversion of a radiative transfer model for estimating vegetation LAI and chlorophyll in a heterogeneous grassland', Remote Sensing of Environment, vol. 112, no. 5, pp. 2592-2604.

Fensholt, R, Sandholt, I \& Rasmussen, MS 2004, 'Evaluation of MODIS LAI, FAPAR and the relation between FAPAR and NDVI in a semi-arid environment using in situ measurements', Remote Sensing of Environment, vol. 91, no. 3-4, pp. 490-507.

Fernandes, R, Butson, C, Leblanc, S \& Latifovic, R 2003, 'Landsat-5 TM and Landsat-7 ETM based accuracy assessment of leaf area index products for Canada derived from SPOT-4 VEGETATION data', Canadian Journal of Remote Sensing, vol. 29, no. 2, pp. 241-258.

Gong, P, Pu, R, Biging, GS \& Larrieu, MR 2003, 'Estimation of forest leaf area index using vegetation indices derived from hyperion hyperspectral data', IEEE Transactions on Geoscience and Remote Sensing, vol. 41, no. 6, pp. 13551362.
Gonsamo, A \& Pellikka, P 2012, 'The sensitivity based estimation of leaf area index from spectral vegetation indices', ISPRS journal of photogrammetry and remote sensing: official publication of the International Society for Photogrammetry and Remote Sensing (ISPRS), vol. 67, no. 4, pp. 15-25.

Haboudane, D 2004, 'Hyperspectral vegetation indices and novel algorithms for predicting green LAI of crop canopies: Modeling and validation in the context of precision agriculture', Remote Sensing of Environment, vol. 90, no. 3, pp. 337-352.

Klimek, S, Richtergenkemmermann, A, Hofmann, M \& Isselstein, $\mathrm{J}$ 2007, 'Plant species richness and composition in managed grasslands: The relative importance of field management and environmental factors', Biological Conservation, vol. 134 , no. 4 , pp. 559-570.

Malenovský, Z, Homolová, L, Zurita-Milla, R, Lukeš, P, Kaplan, V, Hanuš, J, Gastellu-Etchegorry, J.-P. \& Schaepman, ME 2013, 'Retrieval of spruce leaf chlorophyll content from airborne image data using continuum removal and radiative transfer', Remote Sensing of Environment, vol. 131, pp. 85-102.

Mutanga, O, Skidmore, AK \& Prins, HHT 2004, 'Predicting in situ pasture quality in the Kruger National Park, South Africa, using continuum-removed absorption features', Remote Sensing of Environment, vol. 89, no. 3, pp. 393-408.

Mutanga, O \& Skidmore, AK 2007, 'Red edge shift and biochemical content in grass canopies', ISPRS Journal of Photogrammetry and Remote Sensing, vol. 62, no. 1, pp. 34-42.

Myneni, RB \& Williams, DL 1994, 'On the relationship between FAPAR and NDVI', Remote Sensing of Environment, vol. 49, pp. 200-211. 
Ramoelo, A, Skidmore, AK, Schlerf, M, Mathieu, R \& Heitkönig, IMA 2011, 'Water-removed spectra increase the retrieval accuracy when estimating savanna grass nitrogen and phosphorus concentrations', ISPRS Journal of Photogrammetry and Remote Sensing, vol. 66, no. 4, pp. 408-417.

Roberts, DA, Roth, KL \& Perroy, RKL 2012, 'Hyperspectral Vegetation Indices' in Hyperspectral remote sensing of vegetation, eds PS Thenkabail, JG Lyon \& A Huete, CRC Press, Boca Raton, pp. 309-327.

Sampson, PH, Zarco-Tejada, PJ, Mohammed, GH, Miller, JR \& Noland, TL 2003, 'Hyperspectral remote sensing of forest condition: Estimating chlorophyll content in tolerant hardwoods', Forest Science, vol. 49, no. 3, pp. 381-391.

Si, Y, Schlerf, M, Zurita-Milla, R, Skidmore, AK \& Wang, T 2012, 'Mapping spatio-temporal variation of grassland quantity and quality using MERIS data and the PROSAIL model', Remote Sensing of Environment, vol. 121, pp. 415-425.

Skidmore, AK, Ferwerda, JG, Mutanga, O, van Wieren, SE, Peel, M, Grant, RC, Prins, HHT, Balcik, FB \& Venus, V 2010, 'Forage quality of savannas Simultaneously mapping foliar protein and polyphenols for trees and grass using hyperspectral imagery', Remote Sensing of Environment, vol. 114, no. 1, pp. 64-72.

Thenkabail, PS, Smith, RB \& De Pauw, E 2000, 'Hyperspectral Vegetation Indices and Their Relationships with Agricultural Crop Characteristics', Remote Sensing of Environment, vol. 71 , no. 2, pp. 158-182.
Tian, YC, Yao, X, Yang, J, Cao, WX, Hannaway, DB \& Zhu, Y 2011, 'Assessing newly developed and published vegetation indices for estimating rice leaf nitrogen concentration with ground- and space-based hyperspectral reflectance', Field Crops Research, vol. 120, no. 2, pp. 299-310.

Wang, F, Huang, J, Tang Y \& Wang, X 2007, 'New Vegetation Index and Its Application in Estimating Leaf Area Index of Rice', Rice Science, vol. 14, no. 3, pp. 195-203.

Zagajewski, B \& Jarocinska, A 2009, 'Analysis of plant condition of the Bystrzanka catchment', in Proceedings of the $28^{\text {th }}$ EARSeL Symposium, IOS Press, Millpress Science Publishers, pp. 498-504.

Zarco-Tejada, PJ, Miller, JR, Noland, TL, Mohammed, GH \& Sampson, $\mathrm{PH}$ 2001, 'Scaling-up and model inversion methods with narrowband optical indices for chlorophyll content estimation in closed forest canopies with hyperspectral data', IEEE Transactions on Geoscience and Remote Sensing, vol. 39, no. 7, pp. 1491-1507.

Zheng, G \& Moskal, LM 2009, 'Retrieving Leaf Area Index (LAI) Using Remote Sensing: Theories, Methods and Sensors', Sensors, vol. 9, no. 4, pp. 2719-2745.

Zvára, K 2003, Biostatistika, Karolinum, Praha. 